\title{
THE IMPACT OF THE DIGITAL REVOLUTION IN THE DEVELOPMENT OF MARKET AND COMMUNICATION STRATEGIES FOR THE LUXURY SECTOR (FASHION LUXURY)
}

\section{Escobar, A.}

In recent years the luxury industry has been strongly affected by the rapid evolution of digital technology and the internet. The use of the internet and the new digital technologies has contributed to the growth of the market and its different sectors. This meant an advantage for others, but for the luxury sector, it has been a challenge and the adaptation process slow. The online participation - in certain cases incipient - of some brands in the sector has been directed by new consumption habits, which had an impact in the marketing and communication strategies on a managerial level. Based on a theoretical review, this paper proposes a central concept known as brand expression, from which elements involved in the phenomenon of the digital era, some significant for the development of the study, are described. The resulting relations between them, together with findings obtained in interviews of consumers in the sector, describe the reason for the adaptation in content and approach of the current strategies; that in turn sets the guidelines for continuing and future developments.

Keywords: brand expression; communication; consumer behavior; content marketing; digitization

JEL Classification: M31, M37, O33

\section{Introduction}

In the development of societies and therefore of the individuals that integrate them, the adaptation to change plays a crucial role for the future. In a context where digitization has directed the course of a social evolution in the field of communications, technologies already constitute a basic need between sender and receiver; at the same time not only advantages are generated, but also immediate opportunities of knowledge for both. The current media situation in the luxury sector is dictated by the consumers and the use of different digital tools of easy access, which obviously has facilitated the process of communication between client-company and company-client. However, when speaking of luxury, the communication process - in many aspects - may be more complex than is usually believed.

The concept of luxury in its beginnings involved aspects of culture, of lifestyle and especially of high purchasing power of minorities; for example, the European monarchies were distinguished by the eccentricity of their properties and between them began the marketing of luxury, which at the time was equivalent to power and outlined frivolous social differences. With the passage of time, and parallel to society's transformation, the meaning of luxury also evolved.

Today, luxury tries to generate particular experiences, sells visible details such as quality, originality, beauty, personality, art and sensitive ones such as dreams, expectations, aspirations, and intelligentsia. At the same time, it attempts to evoke in customers the feeling of belonging and being special (Gutiérrez de Ravé, 2015). It has even given an important turn referring to ostentation and extravagance, and the concept 
of "less is more" has won importance. From this perspective and from its appearance, luxury has involved a meaning of high value, which currently is not only economic but emotional, from where intangible values, that built brand personality, identity and positioning, arise. Together these three aspects form what is known as brand expression.

The objective of brand expression, from within, has to do with offering a value not only to consumers but also to itself. This is, that in accordance with this concept and oriented to luxury brands, one of the most important values that defines the unique, scarce and exceptional nature of luxury is the tradition, i.e. heritage and history. In general, it is perceived that the luxury brand needs a great history and heritage to support it, in order to be perceived as valuable, prestigious and be strongly positioned in the market (at least this has been a feature of the traditional luxury brands, that through the years remain a reference of quality, prestige and exclusivity. Some examples include: Dior, Louis Vuitton, Prada, Gucci, Ermenegildo Zegna; fashion, design and clothing brands). In addition to high quality materials and design, history and tradition are determinants for luxury brands. They attract consumers, reinforce the brand identity and demand, but they are not the only factors that ensure positioning, survival and success (Melissos, 2013). It is here where communication joins other factors that play a critical role, and where opportunities are generated, ranging from strengthening the image, selling, to creating experiences. Communication in the brand-consumer sense was, until the advent of the digital era, the most common. However, there is now an immediate bilateral communication thanks to communication technologies that have developed tools such as "social media" (online communication platforms connected via the internet. Virtual communities shaped by social networks like Facebook, Twitter, Instagram) and different technological applications; these have renewed the consumer experience and, in the best of cases, added value. An interactive feedback, that allows brands to know the needs, tastes, and even emotions generated by a brand in the consumer, is generated in this way.

Through the use of digital technology, new content that seeks to redefine values has been generated. According to the evolution of its tools, new formulas have been implemented to keep catching the attention of customers, attract new ones and, at the same time, develop significant involvement profiles.

Taking into account aspects such as the impact of the digital era in the luxury sector, the evolution of digital technologies and the exponential growth of the use of the internet (which not only communicates but also reports), this paper seeks, mainly theoretically, to detect, from a central concept known as brand expression, the different elements involved in a process of communication between brand and consumer. The relationship between such elements, in combination with findings obtained in interviews to consumers of the sector, describes the reason for the adaptation in content and approach of the current strategies; that in turn shapes the guidelines for continuing and future developments. The paper has three main sections, presented in the following way:

- Through a literary review the main elements of interest for the development of the paper are described and found; in this first section, there is an exhibition of key statistical data of the sector for the purpose of the investigation.

- Subsequently the obtained findings are presented as part of a qualitative study developed during the second half of the year 2015 in the cities origin of two of the 
major brands in the fashion luxury sector: Prada and Louis Vuitton, specifically in the cities of Milan and Paris, where consumers find insignia stores or flagships of each one of them. The findings are derived from interviews with consumers of the sector detected in the shopping area and the most relevant results are presented for the purposes of this study.

- At last, the final discussion synthesizes the information obtained from the first two sections by way of an analysis where, from the main concept, the elements found throughout the study describing impacts and effects are connected. General implications are described within the conclusions.

\section{Brand Expression}

Brand expression departs from a communication need that makes use of tangible and intangible attributes of the own brand; the latter will define the parameters of the message one wishes to convey to the consumer to achieve a motivation for the purchase and as a final goal, to make it. In this sense, it strengthens the idea on brand expression as a cognitive measure of the brand personality, described in some studies, which will be relevant for the development of emotional, behavioral and subsequently shopping inclinations by the consumers of that brand (Carlson et al., 2009). Therefore, brand expression shall have the objective of defining a consumption experience that will induce the required attitudes and behaviors. Likewise it guides both the marketing mix and the activities to implement, so that the objective is achieved (Van Gelder, 2005).

\subsection{Elements of Brand Expression}

The perception of a brand by the consumer is related to the elements that compose the brand expression; these are: brand (1) personality, (2) positioning and (3) identity. The concept of brand personality was defined by Aaker (1997) as a set of attributes and human characteristics that are associated with a particular brand. As a result, a bond between brand and consumer is generated, which at the same time develops affective elements and builds the basis of a long-term relationship. Continuing with the brand positioning, it is defined as an act that designs the supply and the image of a brand, all in order to occupy a privileged place in the mind of the consumer (Hui-Ju, 2015). This element has communication tools which allow to keep the mind of the consumer with regard to the brand updated. Examples such as word of mouth and currently the different social networks where the consumers interact, not only among themselves but also with the brands, are some of them (Hennig-Thurau et al., 2004). The features of these forms of communication are described below.

Finally, the brand identity establishes its foundations, that is to say, what the brand represents and the aspects related to the brand legacy, its principles, objectives and values (Van Gelder, 2005). According to certain studies, perceiving economic, cultural, sociological and historical brand attributes makes the brand identity grow among consumers (Rajagopal, 2013). Focusing on this last element -- historical brand attributes -- and luxury brands raises the relationship with attributes such as roots, heritage, tradition, values and ambitions, which are part of the identity of luxury brands and thus of their brand expression in general. 


\subsection{Brand Expression in Luxury Brands}

Luxury brands have contextual qualities that differentiate them and give them value, which is directly reflected in consumer preferences. In this sense, brand expression will contribute significantly to the construction of the brand image and, at the same time, of the loyalty among consumers (Rajagopal, 2013). Even the time factor is a benchmark of quality that adds value to the brands of the luxury sector, i.e. these brands have a wide trajectory in the market, sometimes so wide it becomes historical, increases its value and distinguishes it as successful. In addition, regarding the products, the high quality that characterizes them is closely related to consumer loyalty due to the high performance of the products through time. In some cases, the consumer can show displeasure with some brands or products, which is not related with the quality, but rather with the difference in personal tastes and the way in which he perceives the brand.

\subsection{Identifying Key Features in the Elements of Expression of Luxury Brands}

Luxury brands in the fashion sector possess contextual characteristics that define their identity, personality and positioning. They are described below:

- Identity. When a brand has a relevant historical background, it automatically acquires a significant sense and value. In the luxury sector, this feature is shared among those brands that were formed through time making emphasis in their roots and unique qualities, inherited from their founder. All this generates an environment around the brand full of symbolism, histories and even mythology, i.e. beliefs with which the consumer comes to identify himself and by which he reinforces his economic investment, not only for having the product but also for feeling part of the brand history and legacy. Another contextual quality that is part of the brand identity in the sector is the origin of the brand, that is to say, the place where it was born or appeared for the first time, either a city, country or region. Brands tend to carry with them elements of their native lands, which are incorporated into their organizational cultures. These customs, traditions, beliefs and values permeate the organization and influence of the brand, often to their advantage (Van Gelder, 2003). The importance of the origin is strengthened with brands that are in their nature geographical indications, in which the quality and characteristics of the product are attributable to the sole, water, climate and citizens' skills of a specific place, town or region (Štěrbová, 2008).

- Personality. The intrinsic attributes of the product are important; however, studies indicate that brands create even more value for consumers through the construction of significant associations (Fournier, 1998; Chernev et al., 2011). Accordingly, there is a concept called brand affinity from where affective ties with the consumer are developed. Brand affinity includes concepts of complementarity by searching affinity and compatible personalities (Chang, 2008). It was previously described that brand personality builds the emotional bond with the consumer. It makes use of attributes with which it feels identified, attributes of its personality that are related to those of the brand. Van Gelder (2003) indicates that certain specialists in affinity usually make use of traits of the brand personality as a means of expression of the same. This way, it 
will be easier and more attractive for the consumer to relate with a brand that has a clear and strong personality than with one that lacks it. In this sense, Aaker (1997) asserts that consumers express and validate their identity with the use of certain brands. Other recent studies reinforce this idea by indicating that consumers also seek and desire to demonstrate sophisticated knowledge about culture, style and taste (Amaldoss and Jain, 2005; Gutiérrez de Ravé, 2015). In this way, luxury brands can feed different personality facets of consumers, i.e. by issues of status and belonging to social groups on one hand, and on the other, consumers who take them as part of their culture and lifestyle - as is the case in some European countries and currently in a percentage represented by countries of the Middle East. Brand personality provides differentiation; likewise it represents a value proposition for consumers. In addition to intrinsic attributes, it also has extrinsic elements, i.e. visual identifiers, such as logos, design and graphic symbols. For a brand, graphic symbols are part of its personality, they grant value and allow it to differentiate itself from others (Stabler, 2009). However, and according to the opinions of experts in the sector, consumers are changing their preferences and evolving a discrete idea of luxury (Halzack, 2015). Visual elements gradually cease to be relevant to the consumer, which relates to the loss of interest in demonstrating high purchasing power. This new trend in consumption arises from social and economic changes which have a direct impact on the mind of the consumer and therefore on his behavior. The impact is reflected even in the strategies of some brands such as Chanel, which took a risk in 2011 to bring to the market a collection of bags without any type of logo or identifier. This type of practice has given rise to the evolution of luxury marketing. Brand personality and identity are related to certain internal factors of the organizations (van Gelder, 2003). One of these factors is the founder of a brand whose own personality works as the brand itself; this is often the case with design brands such as Giorgio Armani and Yves Saint Laurent. Under this same perspective, the author claims that the brand personality grows naturally from the traditions and histories of the organization itself, i.e. features that make a luxury brand unique and unrepeatable.

- Positioning. In the literature there are various forms that have interpreted this element of the brand expression. In general and in present terms, it has been defined as the place a product or service occupies in the mind of the consumer. But this is only a consequence, i.e. the term (since its appearance) entails a deeper sense when different perspectives defined in the literature are analyzed. The term positioning was first used by the authors Ries and Trout (1981), who visualized it as an exclusive matter of communications in order to have the capacity to handle a position in the mind of consumers; this started with publicizing or communicating the features, attributes and values of brands, products or services that were attractive or consistent with the needs of the consumers. In this way, it was subsequently considered that the positioning is the result of all perceptions, impressions and feelings that consumers manifest toward a specific brand, product or service (Brooksbank, 1994). Therefore, according to the author Sengupta (2005), the brand positioning strategies seek to create the consumer perception according to the characteristics of the company and its products in relation to the competition, and thus, to emphasize those that distinguish it from others. According to this, it can be said that in general brands, products or services make use of positioning to participate in the competition for the customer and to show the benefits and 
advantages provided with respect to others. The marketing programs, therefore, define relevant positioning strategies in order to catch the attention and loyalty of the consumer, by working with all the elements of the marketing mix; and according to subsequent studies, it is stated that to achieve an effective brand positioning, the marketing mix must be used on an integrated, coherent and viable long-term strategy (Cătălin \& Andreea, 2014; Keller, 2008). However, when it comes to luxury brands, positioning strategies are not used under the same perspective as with common consumption brands, or according to experts in the sector, they even do not exist (Expansion, 2009). This assertion stems from the brand identity, i.e. according to this concept applied to brands of great luxury, they are built based on a legacy, history and tradition, i.e. intrinsic values that make them unique and not comparable. Therefore, in accordance with the foregoing, the term competition for brands of great luxury can be applied perhaps only to themselves. And because the competition between brands and in terms of clients involves the concept of scope it results in an antithesis for luxury. This is due to the fact that in the luxury sector, brands are not seeking mass consumption, which would mean to lose exclusivity, to confuse in terms of image and to decrease its scarce nature, which would affect the value and perception on the part of the consumer.

\subsection{The Digital Era of the Luxury Sector}

Before analyzing the relationship that exists between the main concepts of this study, we describe the main characteristics of digital marketing, the elements that compose it and the key data of behavior and use by the consumers within the luxury fashion sector. The different tools that make it up have built channels of communication and have increased the flow of information between consumers. According to Gutiérrez de Ravé (2015), eMarketing or digital marketing - until a few years ago - was not yet sufficiently well explored or exploited by the companies. A form of communication woke up the immediate interest on the part of the departments of marketing and even of finance. The main reasons were cost savings and easy attainment of the preferences and information of the customers.

Digital marketing, according to studies made in the last five years, has redefined the strategies of traditional marketing and is currently an indispensable tool for the competitiveness of the companies in a society that is governed by the movement, the fluidity and the easy access to information at any given time and place. The companies that have become aware of the importance and the growth of the digital era, have begun to invest a greater percentage of their budgets into the development of platforms and tools of digital communication, as well as of fully adapted contents.

Recently, the results of a study called "The Future of Digital Marketing", carried out in 2015, where published by Mondo (digital marketing and technology staffing solutions agency), and it states that in the next 12 to 18 months, companies at the global level, plan to increase their budgets for digital marketing. The latter has not come to replace nor will replace traditional marketing; however, the approaches change and evolve to achieve a useful and effective adaptation that directly impacts the consumer (see Figure 1). Even now, the elements of the marketing mix have adapted to the digital era, which implies a new trend in marketing strategies. 


\begin{tabular}{|l|}
\hline $\begin{array}{c}\text { TRADITIONAL } \\
\text { MARKETING }\end{array}$ \\
\hline Price \\
\hline Place \\
\hline Promotion \\
\hline Product \\
\hline
\end{tabular}

\begin{tabular}{|c|}
\hline $\begin{array}{c}\text { DIGITAL } \\
\text { MARKETING }\end{array}$ \\
\hline Flow \\
\hline Functionality \\
\hline Feedback \\
\hline Fidelity \\
\hline
\end{tabular}

Source: Gutiérrez de Ravé (2015)

After the evolution and adaptation of marketing to the digital era, the information from the different digital tools is considered as the "raw material" of the marketing strategies for companies, and for the consumers, an opportunity for accurate decision making that also allows them to fully engage with the brands, products and services.

An effective digital marketing involves content and quality (Patrutiu Baltes, 2015) that have constantly adapted to the technological development of devices that distribute information and contents. Digital marketing as well as traditional marketing have tangible and intangible elements. On one side, the tangible elements of digital marketing correspond to technological and electronic developments on the part of the IT companies (Information technology), and intangible ones, whose development depends precisely on the investment and budget allocated by the companies for the generation of content available through a variety of virtual platforms (see Figure 2). This has significantly impacted the behavior of the market in the luxury sector.

Figure 2 | Digital marketing tools

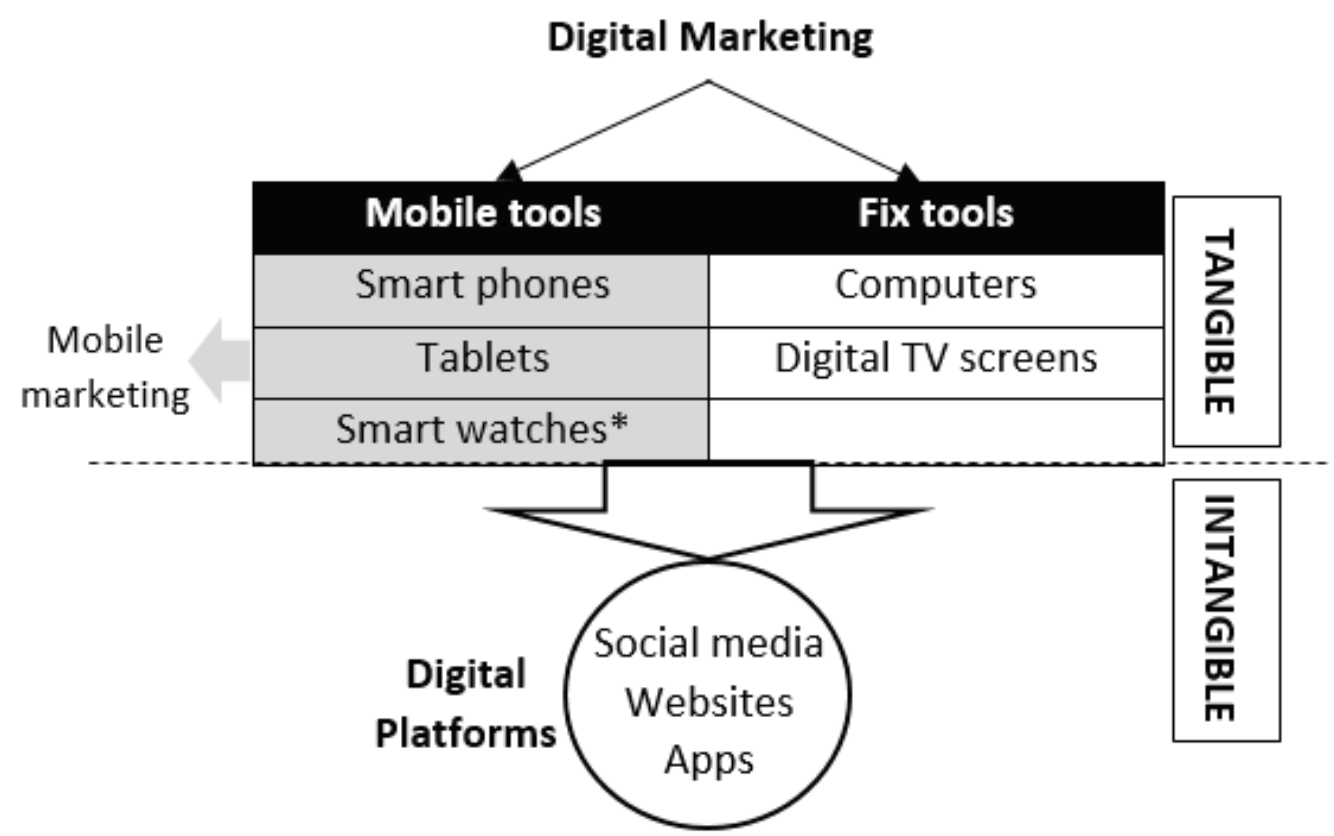

Source: Author 


\subsection{The Role of the Tangible and Intangible Elements of Digital Marketing in the Luxury Sector}

"Mobile marketing" is a term that emerges from one of the five elements of the communication mix, specifically direct marketing. The marketing communications are developed in relation to the evolution of social, economic and technological factors within societies. According to this, mobile marketing (which involves the use of cell phones, smartphones, tablets, and even other digital devices such as watches*) continues to depend, to a large extent, on the technical and technological development of the market (Machková et al., 2010, p. 172). Even despite being today fundamental tools for communication, both consumers and businesses have to deal with issues such as mistrust and fear of the use of personal data that circulates on the net, because it is not easy to control the users and internet users. However, the power these tools of communication have has contributed to the growth of the brands and even more so to its construction. Effective marketing communication has emerged in recent times as an important tool that leads to the involvement of consumers with the brand. According to Andersen (2005), the communication with customers and the participation of consumers in a marketing dialog is vital in relational marketing, which is a prerequisite for achieving involvement and loyalty on the part of them, which in turn has an impact on the possibility of establishing positive market relationships.

In the fashion luxury sector, over the last decade, involvement with the brand has been a result of the intense information movement through social networks (Facebook, Twitter, YouTube, Pinterest, Instagram) and the development, mainly, of websites and mobile applications of some of the most representative brands in the sector, as well as of multibrand retailers and department stores. However, there is still a dispute over to what extent do the brands of great luxury incorporate their presence into sites where they can be reached by the whole world, and where a mismanagement of information can occur and therefore infringe upon their image. At a conference on eRetail in the luxury sector held in Barcelona in January 2016, the following were specifically mentioned: the incorporation of the sector into the digital era, as well as advances and implementation of digital technologies that have contributed to the emergence of new experiences of consumption and at the same time helped to study consumer behavior in this sector. Despite the suggested benefits, the case of Prada was presented, which until the year 2011 did not have a website that would allow consumers to approach the brand using a digital channel (Delso Mion, 2016).

In opposite cases, some studies indicate that the internet and digital platforms are perceived by the luxury industry as a loss of control of their brand image (McKinsey \& Co., 2015). This departs from the idea of keeping the nuclear values intact and therefore the brand identity that one wishes to keep before the market. It was concluded that current websites, which are also visited via mobile devices, are a strategic complement of the communication and the sales of brands in the luxury sector, and therefore the multichannel experiences - both on and off the net - have meant an increase in the flow of information between consumers.

According to the author Rajagopal (2013), several companies are recognizing the advantages of having an enhanced web and developing brand communities online, which empowers the development of the marketing communication and converges effects of the brand with the shopping decisions of consumers. In addition to the foregoing, the inputs and outputs of word of mouth through social networks increase the degree of brand participation among consumers. In spite of the fact that the concept of word of mouth has 
been studied since the 50's (Buttle, 1998) and it seems old, it is one of the most effective ways of communication that currently exist, and according to certain subsequent studies, it has been proved to have a substantial impact on the choice of the product (Bansal \& Voyer, 2000; Layton, 1981). Formerly it was materialized through a personal communication, in direct conversations between consumers who had contact with the product, tested it or acquired it. Today, the use of social networks has reinforced this practice and even in the luxury sector has given rise to the emergence of online services of comprehensive image advisers who help to choose and shop for styles that are in accordance with customer needs. These advisers are known as personal shoppers.

\subsection{Key Data on the Impact of the Digital Era in the Luxury Sector}

Relevant data on the growth and penetration of the digital era in the sector of luxury goods and in specific cases of the luxury fashion sector is presented below. This contributes to the construction of the context under which this article is directed. The data is derived from two studies done in the past two years, "Digital inside: Get wired for the ultimate luxury experience" (2015) and "Luxury Goods: The digital frontier" (2014). The first by the global consultant McKinsey \& Company and Altagamma Foundation. The second corresponds to the companies Exane and ContactLab.

The data is the following:

- The number of luxury consumers has tripled in the last two decades. It has gone from approximately 90 million consumers in 1995 to 330 million by the end of 2013 (Bain \& Co., 2014).

- Joining all categories, the global luxury market exceeded 850 million euros in 2014. In particular, the sector of "personal" luxury goods, was projected to 223 billion euros in 2014 (Bain \& Co., 2014).

- With 14 million euros in 2014 , online sales of luxury products represent approximately $6 \%$ of the market, above the $2 \%$ in 2009 (global average). It is estimated that for the year 2025 , a growth of $18 \%$ will be reached.

- For 2014, luxury sales online grew $27 \%$, while its progression was limited to $7.2 \%$ on other sales channels.

- During 2014, the U.S. occupied the first place (just above 10\%) of the penetration of e-commerce. However, subsequent studies on luxury sales figures online by countries, located the United Kingdom with a market share of $11 \%$. This is due to a quick adoption in the last year of the digital opportunities by the consumers in that country.

\section{Luxury players and online channels}

- Luxury buyers are turning increasingly to the information sources aimed at the products, such as the websites of brands or multi-brand retailers and department stores, with the objective of easily comparing products and prices.

- The participation of the online channels in digital commerce is headed by the retailer sites, with a $35 \%$, Etailer sites $33 \%$ and finally the brand sites with a $32 \%$.

- The luxury players are slow in the construction of digital capabilities, with a few notable exceptions, such as the English origin brand Burberry. 
- Burberry seems to be the only player fully committed with a digital future, offering the comfort of cross channels and the expansion of its presence in mono-brand websites for operations based on the shop-in-shop concession with T-Mall and Amazon.

- Louis Vuitton, Gucci and Tiffany outweigh Burberry in terms of user experience. With the recent developments in its web, Louis Vuitton is offering one of the best digital experiences.

- The luxury players have historically been very cautious in what to electronic digital commerce refers. Brands such as Céline or Fendi, for example, are still in development plans in what to consumer digital involvement refers.

\section{Price and Categories}

- Through the price points, there are significant variations with decreasing online sales as prices rise.

- For high-end brands such as Dior, Cartier and Chanel, the share of electronic commerce is only 3.6\%. For aspirational brands like Burberry, it reaches $7.5 \%$, and for the more affordable luxury brands like Michael Kors or Longchamp it is greater, with an average of $8.5 \%$.

- Fashion is the fourth sector by shopping frequency between online consumers. Ahead are technology and media, leisure-culture and travel.

- The most active electronic commerce categories are those relating to beauty products and prêt-à-porter clothing (ready to wear), both with a $7.2 \%$ of the sales, followed by accessories with a $6.2 \%$ and finally, watches and jewelry with $4.1 \%$.

\section{Consumers and digital devices}

- $95 \%$ of the luxury consumers have a mobile device, compared to $60 \%$ corresponding to the rest of the consumers, regardless of age. $75 \%$ of the luxury consumers have more than one mobile device.

- Luxury consumers, divided in Generation Y or Millennials (18-35 years) and Baby Boomers ( $>65$ years) have similar amounts of mobile devices and on average surf the same time on the Internet, approximately 15 hours per week, without any job related use. The generational gap is identified in the use of social media, with $97 \%$ of the Millennials versus $71 \%$ of the Baby Boomers.

- Women have a market share of more than $60 \%$ in terms of online shopping.

- With regard to the uses and habits of online shopping, consumers prefer the personal computer $(83 \%)$ over the remaining $17 \%$ corresponding to other digital devices.

- The use of the mobile apps has had an increase of $15 \%$ in 2014 , representing a percentage of $40 \%$ of the electronic commerce.

\section{Online influence in the purchase}

- In $2013,40 \%$ of luxury shopping was somehow influenced by the digital experience of consumers through the investigation of an online article or digital social media, which later lead to a purchase in store.

- For the year 2015, studies revealed that three of every four luxury purchases, even if they were made in person at the stores, were influenced by what consumers saw and heard online. 


\section{Identifying Other Relevant Intangible Elements to Consumers}

Results derived from a qualitative study conducted last year in cities of origin of two major brands in the fashion luxury sector: Prada and Louis Vuitton, specifically in Milan, Italy and Paris, France reveal part of the current behavior, usage trend and online information interests on the part of the consumer. For the purposes of this article, only the key findings obtained from interviews with buyers (identified customers with purchase in store) and non-buyers (identified customers without purchase that entered the store) are presented. In addition, the interviews had the characteristic of a meaningful involvement, i.e. they lasted on average 10 to 12 minutes. We present the responses of a total of 150 interviewed persons, of whom 93 (62\%) were women and 57 (38\%) men, between 22 and 55 years of age. They were addressed leaving the place (store). They used sampling by quota.

\subsection{Key Findings}

The number of respondents was separated into two groups (A) and (B) according to the age. In group A (110) are located the consumers between 22 to 35 years, and it contains the group of Milennials (born between the decades of the 80's and 90's). In group B (40) are consumers from 36 to 55 years, in this group are located part of the Baby Boomers (born between the last years of the 40's until the 60's). Different behaviors were identified in the use of digital tools and online information.

Group A was characterized by a high use of social networks as a first point of online contact and immediate source of information. It was denominated by the study of "low content", i.e. only through images, comments and short advertisements reporting novelties. Instagram and Twitter are the most recurrent media in this group, followed by Facebook and YouTube (see Figure 3). Subsequently, a second point of contact is identified, denominated by "high content", where there are mentions of websites as monobrand sites or of the own brand, sites of the designers themselves, multi-brand sites of eTailers (only online presence) and retailers (online and physical presence).

Figure 3 | Group A

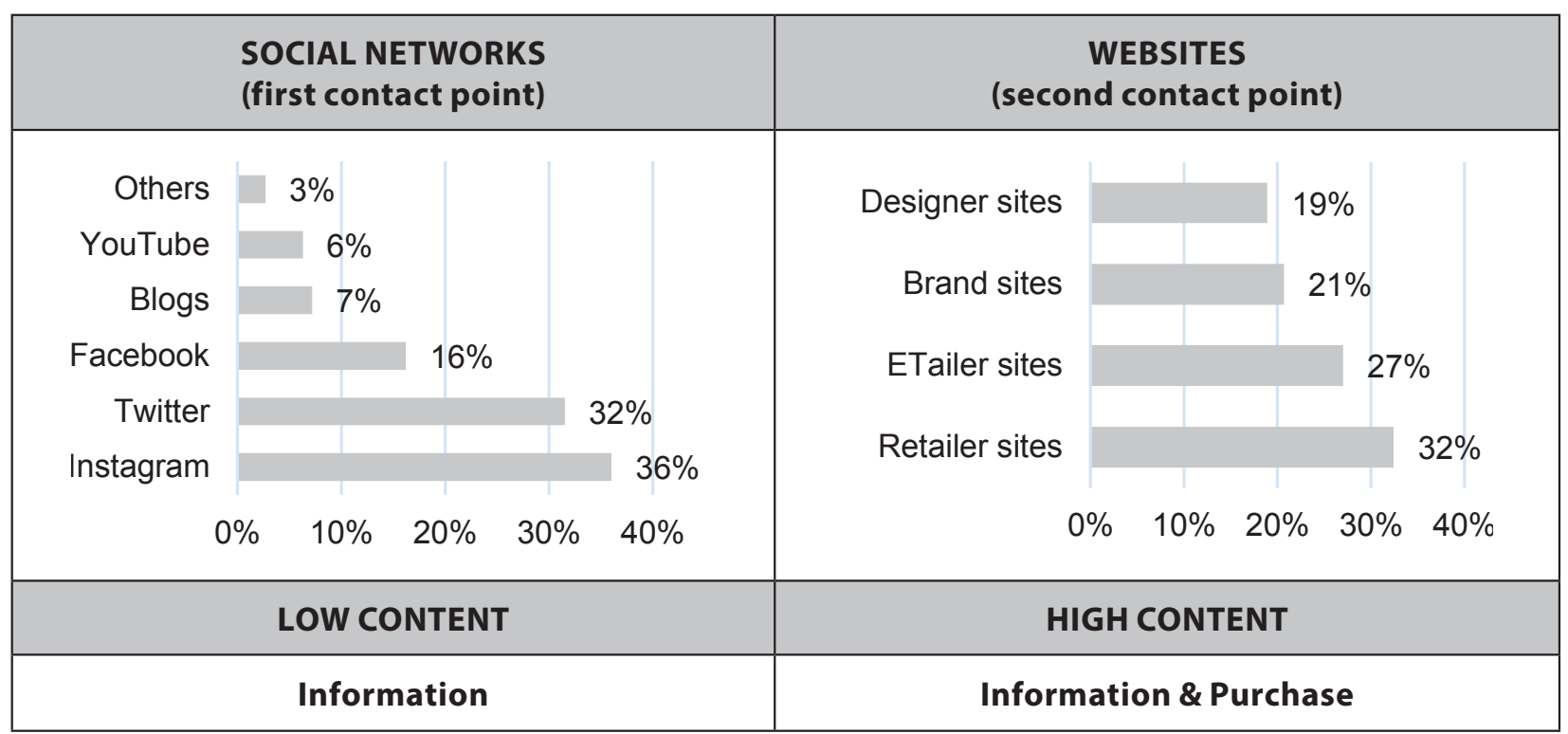

Source: Author, $\mathrm{N}=110$ 
Websites, according to the responses of the consumers in this group, not only offer visual material such as galleries of images and videos, but also services such as chats, shopping, and digital activity and interaction, allowing them to experience new and different ways of consumption. In addition, they have extensive information of the brands or products, history and data of interest; they are, therefore, denominated of high content. As well as search for more complete information in this type of sites, the buying activity of the interviewees is mentioned. In special cases, the applications available for smartphones from the brands are mentioned; in other cases, multi-brand applications are described as of a greater utility. In part, this is due to the low presence of the brands in the world of mobile applications; it has not been detected as an important development and therefore the consumer is not familiar with their use. Surfing through online stores for applications, the brands that could be identified with an available app are Gucci, Prada, Louis Vuitton and Dior.

On the other hand, group B makes a lesser use of social networks but it does reflect online activity. These consumers indicated to be more informed on trends, new products and brands due to their social activity, such as sporting, social and business events and in consumer communities of common interests related to the luxury sector. The word of mouth stands out in this type of activities. However, outside of the social environment, some of the interviewees mention that the young members of their families are the ones who lead them to the online activity, and they are also involved in the digital environment through their occupational activities. Some of the more involved in it mention frequent consultation of websites and of specific multi-brand sites, where they can make comparisons of price and style, as well as to anticipate trends and fashions. In particular cases, the use of personal shoppers is mentioned, who as mentioned, are agents contacted online who provide a service of shopping experience, advice or both. They can combine online and offline experience; however, some consumers mention that the purely online service is effective and saves time, accessibility, distance and even information and price barriers.

Differences between the two groups were similarly identified for the case of online search interests and objectives. The following was found:

GROUP A - Social Media are conduits that lead the consumer to interact via websites and other digital channels, since through social networks online events such as fashion shows and runways of designers and brands go viral. It was mentioned that some celebrities and public figures are identified as fashion trendsetters; therefore their profiles or accounts are included in their social networks and become, in certain cases, influencers of use or shopping. Consumers that reflect a high involvement in the sector were identified due to mentioning the relationship certain brands have with culture and art, and since this is aligned with their personalities, they are interested in blogs or websites related to their interests. However, the vast majority did not demonstrate a concern for the nuclear information or historical data of the brand, even though they are available in their different websites. The construction of the brand image happens in fact through the user experience. They are more attached to "curious" and immediate data on them, located easily on the net. A special feeling was detected against the presence of digital banners or sites advertising that appear inadvertently while the consumer is making use of the net. Another search of online information sought by the consumers of this group is the one related to the product materials and manufacture and their relationship with the environment. 
GROUP B - this group had the particular characteristic of making practical use of digital tools, which allow them to easily identify their interests. They prefer to have a direct experience with the brands and products in stores; however, more than half coincided that they find it attractive to surf on the brands' and designers' sites, as well as in the new forms of online advertising of articles and brands. Between them they emphasized short videos (storytelling); virtual galleries where at the same time the products are presented, art, design and nature are involved. Like the majority of the consumers of Group A, they are also characterized by interest in the materials with which the products are manufactured and are more familiar with the additional services the brands offer (such as spas, hotels and coffee shops). In approximately half of the cases, a concern for environmental issues and the social responsibility of companies was detected, and information was obtained mainly through websites. They have been quickly involved into the digital era; however, the majority of the cases coincided in not devoting too much time to the actual search of central information of the brands. They claim to have a prior knowledge of them, derived from the tradition of shopping and usage over time. Practicality and knowledge were characteristics that identified this referential group. The digital era represents for them an advantage in effectiveness and shopping time. Men were more identified with time savings, practicality and experimenting with new ways of consumption.

In general, the findings in the interviews show a great involvement of the consumers with the digital technologies and tools, and in spite of not being a fully representative sample, it provides important data for the purposes of this study. A significant degree of influence of the net is identified in the decision-making. It follows that consumers are highly visual and dynamic, which suggests a multichannel presence for the brands. The level of knowledge on the brands and products is high; however, information is obtained in a different way according to age, since taking into account only online sources, the use of social networks is greater in the Millennials group than in the Baby Boomer group. In some cases (less than half), this last group related the brand online presence with quality. It follows that all those interviewed are attracted by technology and the digital era, which has impacted their consumption habits. Shopping intent increases as they spend time on the net, and the interest for a brand, retailer or eReatiler increases as they detected a good performance of their website.

\section{Analysis of the Relationships and Effects of the Digital Era in the Brand Expression, From the Theoretical Review and the Findings in the Interviews to Consumers}

Luxury brands are leaders; they transmit power, energy and dynamism. Currently a way to transmit those values not only to the market but to consumers, is knowing how to adapt to time and circumstances (Gutiérrez de Ravé, 2015). Brand expression, as mentioned, arises from a need of communication that seeks to establish the foundations for constructing effective relationships with consumers. Its elements contribute to the construction of a brand image and to the development of loyalty (Van Gelder, 2003). Currently, for companies and in general for the market, the technological development of the last decade has revolutionized the management of communications, and becomes an advantage when these advances are well utilized, both by the companies and by the consumers. Some studies suggest that the company does not create or deliver brand value 
to passive clients, but it does to active ones, i.e. this characteristic in the clients is due to the bidirectional interactions between the companies and the clients that, through active dialog, encourages the co-creation of brand value (Rajagopal, 2013). According to this statement, it is understood that a dynamism between the participants in the communication process at market level is important for the current development of the brands. Today this is due in large part to the use of the Internet and online tools; and that according to studies and statistics, it has been proven a significant increase in its use, which means a revolution for marketing strategies.

The main purpose of this study focused on the undeniable exponential growth of online activity in the luxury industry - specifically in the fashion sector - in recent years, which has involved both the consumer and the brands. On one hand, we review the particular case of the consumer, who through the use, interests and current characteristics, has issued guidelines for new strategies of various brands in the sector and aroused the interest of others. On the other hand, and oddly enough, from the perspective of the brands, their foray into the online and digital world has been slow; and until a few years ago, it was still an unexplored field for some of them. All this, resulting because of different aspects and conceptions that defined them and are derived from the core of their nature, mentioned above. Departing from these phenomena, and based on the current online behavior of both - consumer and brand - the study set out to find the elements that establish a dynamic and bilateral relationship among them; in addition, they give rise to lay the foundations for new communication strategies on the part of the brands, without detaching from the values and nature that defines them.

\subsection{Discussion}

As a result of the used methodology, such significant elements for the study are analyzed and defined. Subsequent to the joint analysis of the theoretical and practical findings, the relationship of the elements involved in the study is presented. Brand expression is the main concept from which the various presented relationships are derived, taking into account their components and different attributes.

One of the main effects that was detected in the brand expression - departing from the digital era evolution - is the reinterpretation of values of the own brand, through the creation of contents that have a positive impact on the consumer. According to the obtained information from the interviews, a positive involvement with the new trends of advertising, that reflect the brand identity and are attractive to the consumer, is identified. Currently, brands have opted to communicate through stories about who the company is. A technique that has been well used by strong brands that wish to project authenticity as a real value (Denning, 2006). Therefore, in accordance with Patrutiu Baltes (2015), content marketing must be based on the company's values, and its effectiveness will also depend on the choice of the appropriate channels to reach the target audience.

Today, companies wishing to become or remain competitive in the digital market, must adapt and develop marketing content according to their goal and especially, distributed among the appropriate social networks (Patrutiu Baltes, 2015). Holbrook (2001) described the internet as a tool that provides the opportunity for consumers to publicly display their own lifestyles, consumption behaviors and use of products. After a few years this not only affected consumers, but companies as well. The development of the internet has brought with it the emergence of enhanced and effective websites, but above all social networks, 
considered as tools of high impact on consumers and that for companies mean a flow of information of high value. According to the Industry Report for 2013 given by Social Media Marketing, $86 \%$ of sellers consider social networks as one of the most important tools for companies (Lee et al., 2015).

Departing from the technological and digital development, a relationship arises between brand expression and shopping experience. This relationship, which involves the brand value, is located on the contact points that, thanks to the digital tools and platforms, put precisely the consumer in contact with the brand. The consumer is faced with a world of information before the actual decision to purchase and it happens so around him, that the critical points of contact with the brand or product, define not only the result of his decision to purchase, but his shopping experience in general (Mckinsey \& Co., 2015). For companies in the sector, one of the main attention focus points should be to take the decision to invest in technological and digital development that allows them to adapt to the market demands and to the consumption trends dictated by the consumers. The consumer tends to be multichannel, therefore, companies that support the brand in different contact points, will increase their value as the brand becomes more famous (Rajagopal, 2013). According to the foregoing, the multichannel presence of brands in the net will impact positively the involvement of the consumer.

In regard to the personality, as an element of brand expression, it seeks to keep establishing long-term relationships through affective elements developed from its attributes, and that connect the consumer on an emotional level. The development and communication of the emotional values of the brand may increase the creation of value and be a means to develop a sustainable differential advantage (Lynch \& Chernatony, 2004). This leads to a discussion on the idea of the existence of competition among luxury brands. It was mentioned in this study that there are statements of experts on the idea that competition does not exist among luxury brands. Their nature makes them unique and not comparable among themselves. According to Gutiérrez de Ravé (2015), there are more luxury brands and therefore competition; however, it is necessary to have a "unique selling proposition" or "unique sale proposal", i.e. a real or intangible benefit that differentiates the brand from another that sells the same product or service, something that makes it unique. Then the question arises, how is this related to the online and digital world? In this sense, the importance of content marketing returns, that according to the Content Marketing Institute (2015), is a process of marketing for the creation and distribution of relevant and valuable content to attract and to conquer a target audience clearly defined and understood, with the aim of boosting the profitable action of the client. Making use of the currently available digital tools, you can create highly attractive content for the consumer. The foundations of loyalty are established through content quality and the appropriate use of social networks and online media that positively relate the consumer with the brand and make it profitable.

With regard to the findings of the interviews, the practicality of the digital tools means an advantage for the consumers as web users, and in that regard, they expect to obtain information of the brands or products immediately and to connect their interests in an effective manner. In content marketing, according to Gupta (cited in Patrutiu Baltes, 2015), the content is created and defined to provide consumers with the information they seek. It is therefore clear that the marketing contents more than quantity must appeal 
to the quality; this will generate more opportunities to increase the emotional ties with the consumer and therefore loyalty. As a result of the analysis, the relationship of the involved elements obtained from the development of the study, is the following:

Figure 4 | Relational model

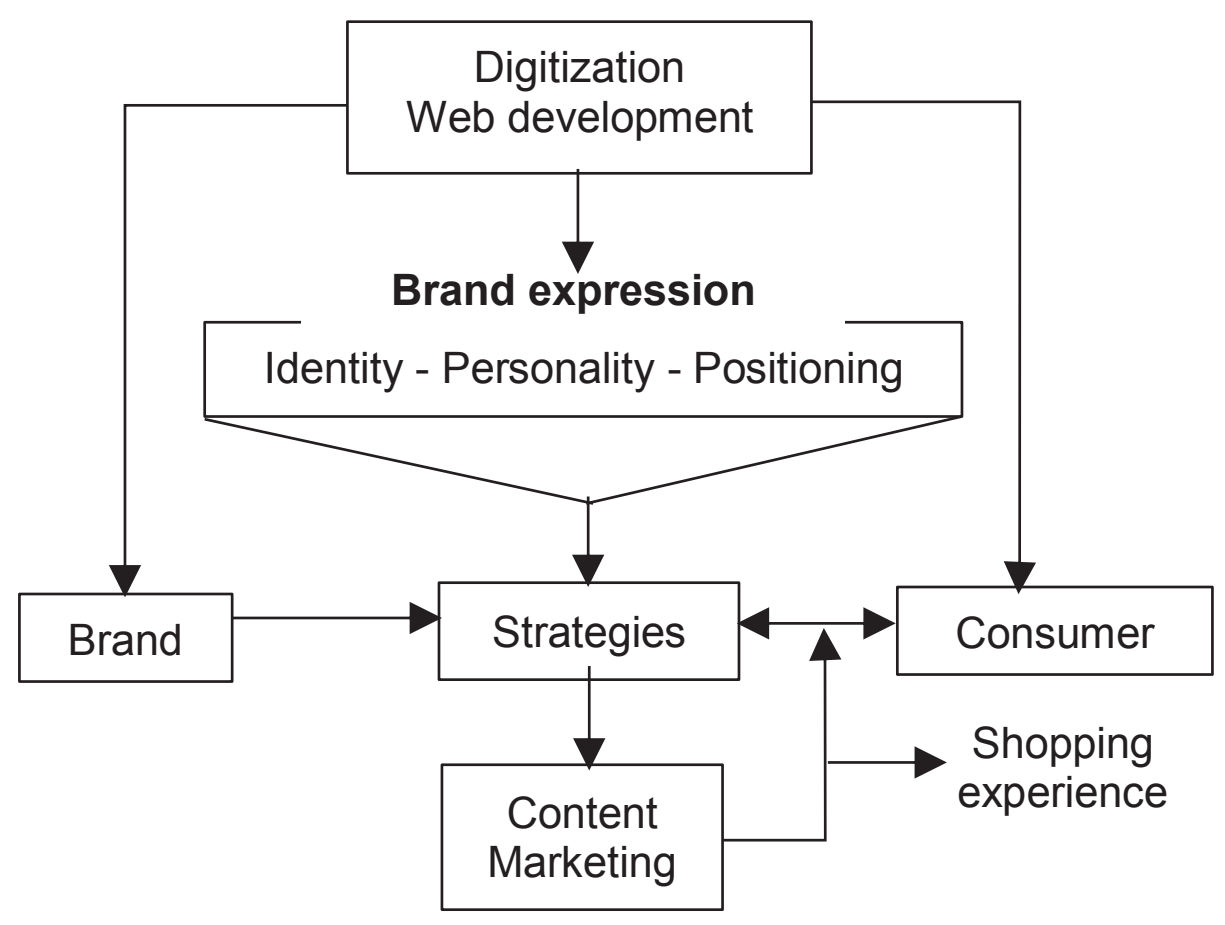

Source: Author

The previous model shows the relationships between the main concepts presented in the study, as well as the elements that are involved throughout the development and subsequent analysis of the same. The connection between consumer and brand through digitization or technological development has been defined; for the purposes of this paper, it focused on digital tools of communication, ranging from digital platforms, social networks, to the different electronic devices that the consumer manages. The impact of digitization in brand expression as the central concept leads it to redefine and re-route the components of its three elements, so they can adapt to the digital era, without affecting the original attributes that built its image and support it. This translates to new guidelines for marketing strategies with the objective to positively impact the consumer, who is shown with a bidirectional relationship, since he from his use and behavior in the digital world, will establish the patterns of such strategies. Therefore, a dynamic and bilateral communication that allows new communication technologies to generate a flow of information of high value where interests and consumer trends, which should be taken into account by the companies for the development of effective business strategies, will be known. These strategies, as indicated by the model, will be represented and related to content marketing, which will retake the most important attributes of the brand expression for its construction; a direct relationship is therefore indicated with the concept of brand expression through the strategies. They will also be routed to the process of communication and involvement with the consumer; therefore their impact is located 
between him and the strategies. At the same time, a relationship is established between the content marketing and the shopping experience, which will increase the brand value as it achieves a positive impact on the consumer. This depends again on the quality of the content marketing, not only with reference to the information that the message one wishes to transmit contains, but to the different tactics generated to involve the consumer.

\section{Conclusion and Implications}

"Designers and luxury houses must find a balance between traditions and the power exercised by the new technologies and social networks, which open up new and enormous possibilities for the consumer" (Gutiérrez de Ravé, 2015). "Customers today are aware of the power they have in the market and that any activity is performed for them" (Shaon \& Rahman, 2015).

The impact of the digital era in the market is substantial and progressive. The true challenge of luxury brands is not to compete for the greatest number of customers, in any case is for the higher number of adaptations to change, innovate and understand the current, potential and yesteryear consumer. Accordingly, they ensure an important presence in the market and among consumers. The adaptation of elements of brand expression to the digital era, according to the increase in the use of the net by consumers, is only one perspective more within the universe of marketing, appropriate to the current technological evolution and looking to face a future expected to be dominated by it. However, until now there has been no technological tool that suppresses or exceeds the emotions and sensations generated by direct contact with people and the environment. At the end the goal is tangible, i.e. in the case of the market, there may be all kinds of roads that connect the consumer with the product, but the idea will always be to possess it.

The synthesis between findings in the literature and the responses to interviews, give rise to the following implications:

- Economies of scale: Their application can represent benefits to businesses, beyond economic ones, and are manifested in an improvement of products and experiences. The flow of information through the net and digital tools has positively affected the costs. An example that should be taken into account, is the bilateral character of today's communications thanks to the development of digital technologies. It should be recalled that a decrease in costs, according to economies of scale, does not necessarily represent a decrease in the quality of the product or service. The creativity is included in this concept as part of the improvement in shopping experiences, if the available resources due to digital technologies and the net are well exploited and directed (to the correct targets) by companies.

- A good service performance increases the interest of the consumer and therefore his loyalty.

- The online strategies should be focused on a determined target according to his interests, behaviors and identified uses. It is important to emphasize the difference between the real consumer and the potential one in the luxury sector. Characteristics and classical values, search for customization and new values as social commitment and sustainability, differentiate one from the other.

- The shopping experience will form part of the brand positioning, as an element of high impact. 
- Technological resources collaborate with the current construction and renovation of the brand image; however, the power remains on the side of the consumer, it is necessary to generate messages that do not infringe against their own image; this means taking into account social values and principles to which the consumer can be susceptible.

- The success of an effective communication will depend on the quality of the contents of the message; it is also positively correlated with an involvement on the part of the consumer with the brand, regardless of whether there is a purchase or not.

- The elements of brand expression currently are reinforced through the use of communication technologies. The benefits shall be perceived to the extent of a more adapted message to the behavior and interests of the consumer, so he can take more accurate decisions with more and better information, what will save time and improve his shopping experience.

- The information must be accessible; luxury can always keep its value of exclusivity.

The development of digital technologies in the luxury sector represents at the same time for the brands, an adaptation and an opportunity to continue to be linked to the consumer in a more effective way, responding to his needs and behaviors within the market. Information, thanks to new technologies, is dynamic, going from one extreme to the other in the market; it helps the consumer build perceptions and the companies to catch them. This indicates the start of a process of communication that, while making use of the appropriate tools, comes to be effective and profitable.

\section{References}

Aaker, J. L. (1997). Dimensions of brand personality. Journal of marketing research, 347-356.

Amaldoss, W., \& Jain, S. (2005). Conspicuous consumption and sophisticated thinking. Management science, 51(10), 1449-1466.

Andersen, P. H. (2005). Relationship marketing and brand involvement of professionals through web-enhanced brand communities: The case of Coloplast. Industrial marketing management, 34(1), 39-51.

Brooksbank, R. (1994).The Anatomy of Marketing Positioning Strategy. Marketing Intelligence \& Planning, 12(4), 10-14.

Bansal, H. S., \& Voyer, P. A. (2000). World-of-mouth processes within a services purchase decision context. Journal of Service Research, 3(2), 166-177.

Bain \& Co. (2014). Luxury Goods Worldwide Market Study. Retrieved March 1, 2016, from http://www.bain.com/bainweb/PDFs/Bain_Worldwide_Luxury_Goods_Report_2014.pdf

Carlson, B.D., Donavan, D.T. and Cumiskey, K.J. (2009) Consumer-brand relationships in sport: Brand personality and identification. International Journal of Retail \& Distribution Management, 37(4): 370-384.

Cătălin, M. C., \& Andreea, P. (2014). Brands as a mean of consumer self-expression and desired personal lifestyle. Procedia-Social And Behavioral Sciences, 109, 103-107.

Chang, C. (2008). Chronological Age versus Cognitive Age for Younger Consumers: Implications for Advertising Persuasion. Journal of Advertising, 37(3), 19-32

Chernev, A., Hamilton, R., \& Gal, D. (2011). Competing for consumer identity: Limits to self-expression and the perils of lifestyle branding. Journal of Marketing, 75(3), 66-82. 
Contactlab, Exane (2014). Luxury Goods: The Digital Frontier. Contactlab.com. Retrieved February 8, 2016, from http://www.contactlab.com/en/wp-content/uploads/sites/2/2014/10/Luxury_ DigitalFrontier_ReadySteadyGo_ClabExa141009.pdf?lang=en.

Buttle, F. A. (1998). Word of mouth: understanding and managing referral marketing. Journal of strategic marketing, 6(3), 241-254.

B2B Content Marketing (2015). Retrieved February 13, 2016, from http:// contentmarketinginstitute.com/wp-content/uploads/2014/10/2015_B2B_Research.pdf.

Delso Mion, C. (2016). Luxonomy ¿Es el eRetail el 'nuevo dorado' en el sector de lujo?, Imagen internacional y acceso a otros mercados online. In Congreso eRetail en el sector del lujo y premium. Luxonomy, Barcelona. España (January 28, 2016).

Expansión Catalunya (2009). Los principios del antimarketing de lujo. Retrieved February 5, 2016, from http://www.expansion.com/2009/04/28/catalunya/1240949233.html.

Fournier, S. (1998). Consumers and Their Brands: Developing Relationship Theory in Consumer Research. Journal of Consumer Research, 24 (March), 343-73.

Gutiérrez de Ravé V., P. (2015). Lujo Digital, Manual y estrategias. [Digital version]. Internet Business Education and Management Europe.

Halzack, S. (2015). Louis Vuitton, Gucci y Prada están en problemas. Eleconomista.com.mx. Retrieved February 6, 2016, from http://eleconomista.com.mx/industria-global/2015/06/27/ louis-vuitton-gucci-prada-estan-problemas.

Hennig-Thurau, T., Gwinner, K. P., Walsh, G., \& Gremler, D. D. (2004). Electronic wordof-mouth via consumer-opinion platforms: What motivates consumers to articulate themselves on the Internet? Journal of interactive marketing, 18(1), 38-52.

Keller, K.L. (2008). Strategic brand management - Building, measuring and managing brand equity, Upper Saddle River, NJ: Prentice Hall.

Kiel, G. C., \& Layton, R. A. (1981). Dimensions of consumer information seeking behavior. Journal of marketing Research, 233-239.

Lee, E., Kim, Y. J., Lim, Y. S., \& Kim, M. (2015). Trait reactance moderates Facebook users' irritation with brand communication. Social Behavior and Personality: an international journal, 43(5), 829-844.

Lynch, J., \& De Chernatony, L. (2004). The power of emotion: Brand communication in business-to-business markets, The Journal of Brand Management, 11(5), 403-419.

Machková, H., Král, P., Lhotáková, M., Karlíček, M., Malý, J., \& Štěrbová, L. (2010). International marketing. Prague: Oeconomica Publishing House.

Maddox, K. (2015). Study: 80\% of Companies Will Increase Digital Marketing Budgets. Adage.com. Retrieved February 2, 2016, from http://adage.com/article/ digital/80-companies-increase-digital-marketing-budgets/296814/.

McKinsey \& Co. (2015). Digital inside: Get wired for the ultimate luxury experience. Retrieved February 14, 2016, from https://www.mckinsey.de/sites/mck_files/files/dle-2015-globalreport.pdf.

Melissos, J. (2013). Heritage and Innovation in Luxury Fashion Branding - MA Innovation Management. MA Innovation Management. Retrieved February 4, 2016, from http://mainnovationmanagement.co.uk/2013/06/11/ heritage-and-innovation-in-luxury-fashion-branding/.

Mondo (2015). Future of Digital Marketing. Retrieved February 8, 2016, from http://www.mondo. com/the-future-of-digital-marketing/. 
Holbrook, M. B. (2001). The millennial consumer in the texts of our times: Exhibitionism. Journal of Macromarketing, 21(1), 81-95.

Patrutiu Baltes, L. (2015). Content marketing-the fundamental tool of digital marketing. Bulletin of the Transilvania University of Brasov. Series V: Economic Sciences, 8(2).

Rajagopal (2013). Brand Expressions in Stimulating Consumer Behavior in Mexico: An Empirical Analysis. Latin American Business Review, 14(1), 29-53.

Ries, A., \& Trout, J. (1981). Positioning: the battle for your mind. New York: McGraw-Hill

Sengupta, S. (2005). Brand positioning: strategies for competitive advantage. Tata McGraw-Hill Education.

Shaon, S. K. I., \& Rahman, M. H. (2015). A Theoretical Review of CRM Effects on Customer Satisfaction and Loyalty. Central European Business Review, 4(1), 23.

Stabler, R. W. (2009). Quantifying the Effect of a Logotype on Perceived Market Value of Consumer Products. Indiana Undergraduate Journal of Cognitive Science, 4(4), 17-35.

Denning, S. (2006). Effective storytelling: strategic business narrative techniques. Strategy \& Leadership, 34(1), 42-48.

Štěrbová, L (2008). Využití zeměpisných označení k posílení komunikační úlohy značky.:In: Kubina, M. et al. (Eds) Návrh foriem marketingovej komunikácie pre podporu zavádzania nových mulitmediálnych produktov do praxe. Žilina: EDIS - Vydavateĺstvo Žilinskej university.

Van Gelder, S. (2005). Global brand strategy. Sterling, Va.: Kogan Page Ltd.

Wang, H. J. (2015). A new approach to network analysis for brand positioning. International Journal of Market Research, 57(5), 727-742.

\section{Author}

\section{Andrea Escobar Rios}

Ph. D. Student

Instituto Tecnológico y de Estudios Superiores de Monterrey

Campus Ciudad de México

Calle del puente \# 222, Ejidos de Huipulco, Tlalpan C.P.14380, Mexico City.

andreatato_29@hotmail.com

The author thanks specially Doc. Ing. Ludmila Štěrbová (University of Economics, Prague), Doc. Alejandro Medina Márquez (ITESM Campus Ciudad de México) and Oleksandre Petrovskyi (Metropolitan University Prague) for providing assistance and support to this research. 